\title{
Pengembangan Profesionalitas Guru Pendidikan Agama Islam Di Sekolah Menengah Atas Primaganda Jombang
}

\author{
Solikhin \\ Sekolah Tinggi Manajemen Informatika dan Komputer ERESHA Tangerang \\ Selatan, Indonesia \\ e-mail: solikhin50501993@gmail.com \\ Ali Mustofa \\ Sekolah Tinggi Ilmu Tarbiyah Al-Urwatul Wutsqo Jombang, Indonesia \\ e-mail: aljep_90@yahoo.com
}

\begin{abstract}
Teacher professionalism is very important. Moreover, PAI teachers, because the PAI teacher profession must be able to be a role model for students. The main task of the PAI teacher is to improve morals or morals, and instill faith and devotion in the hearts of students. Basically, PAI teachers at PRIMAGANDA Jombang High School gave positive thinking to their professional development through various methods carried out, both from within themselves such as quality development such as attending training and others. For example, the training that has been attended by PAI teachers, namely the Subject Teachers' Conference (MGMP), meetings between high school teachers, attending work shops or upgrading conducted by the Minister of Education and Culture, Jombang. Such an attitude gives the view that the professionalism of a Muslim teacher is not just a teacher in educating his students, but people who are obliged to remind each other that as servants of God are obliged to carry out worship that has been outlined by Him to us. Supporting factors in the development of PAI teacher professionalism are support from school principals and Waka curriculum. In addition, adequate facilities and infrastructure, teacher welfare (salary increase) certification allowances and awards, while the inhibiting factors are lack of funding and less time in learning PAI.
\end{abstract}

Keywords: PAI Teacher Professionalism

\section{Pendahuluan}

Menurut UU RI No. 2 Tahun 1989, Bab I, Pasal 1, Pendidikan merupakan usaha sadar untuk menyiapkan peserta didik melalui kegiatan bimbingan, pengajaran dan latihan bagi peranannya di masa yang akan datang. Menurut Buchori, pendidikan yang baik adalah pendidikan yang tidak hanya mempersiapkan para peserta didiknya untuk suatu profesi atau jabatan, tetapi tidak menyelesaikan masalahmasalah yang dihadapinya dalam kehidupan sehari-hari (Oemar Hamalik, 2010, p.2).

Profesi guru pada saat ini masih banyak dibicarakan orang atau masih saja dipertanyakan orang, baik dikalangan para pakar pendidikan maupun di luar pakar 
pendidikan. Siapa saja yang menjalankan tugas sebagai pengajar, maka ia pun telah melaksanakan tugas yang amat besar (Labib, 2004, p 18). Selama dasawarsa terakhir ini, hampir setiap hari media masa khususnya media masa cetak baik harian maupun mingguan memuat berita tentang guru. Ironisnya berita-berita tersebut banyak yang cenderung melecehkan posisi guru, baik yang sifatnya sangat pribadi ataupun umum. Sedangkan dari pihak guru sendiri nyaris tak mampu membela diri.

Masyarakat atau orang tua muridpun kadang-kadang mencemooh dan menuding guru tidak kompeten, tidak berkualitas dan bahkan pada kenyataannya dilapangan banyak oknum yang berprofesi guru melakukan tindakan asusila atau tindak pidana lainnya. Sikap perilaku masyarakat tersebut memang bukan tanpa alasan, karena memang ada sebagian kecil oknum guru yang melanggar atau menyimpang dari kode etiknya.

Anehnya, kesalahan sekecil apapun yang diperbuat guru mengundang reaksi yang begitu hebat di masyarakat. Hal ini dapat dimaklumi karena dengan adanya sikap demikian menunjukkan bahwa memang guru seyogyanya menjadi panutan bagi masyarakat sekitar. Dan untuk menjadi seorang guru tidaklah mudah seperti yang dibayangkan orang selama ini. Mereka menganggap hanya dengan memegang kapur dan membaca buku pelajaran maka cukup bagi mereka untuk berprofesi sebagai guru.

Guru dalam Islam adalah orang yang bertanggung jawab terhadap perkembangan anak didik dengan mengupayakan seluruh potensinya, baik potensi afektif, potensi kognitif, maupun potensi psikomotorik. Guru juga berarti orang dewasa yang bertanggung jawab memberikan pertolongan pada anak didik dalam perkembangan jasmani dan rohaninya agar mencapai tingkat kedewasaan dan mampu berdiri sendiri dalam memenuhi tugasnya sebagai hamba Allah SWT, serta ia mampu sebagai makhluk sosial dan makhluk individu yang mandiri (Muhamad Nurdin, 2004, p 156).

Guru dalam Islam sebagai pemegang jabatan profesional membawa misi ganda dalam waktu yang bersamaan, yaitu misi agama dan misi ilmu pengetahuan. Misi agama menuntut guru untuk menyampaikan nilai-nilaia ajaran 
agama kepada anak didik, sehingga anak didik dapat menjalankan kehidupan sesuai dengan norma-norma agama tersebut. Misi ilmu pengetahuan menuntut guru untuk menyampaikan ilmu sesuai dengan perkembangan zaman (Muhamad Nurdin, 2004, p 156).

Profesional adalah pekerjaan atau kegiatan yang dilakukan oleh seseorang dan menjadi sumber penghasilan kehidupan yang memerlukan keahlian, kemahiran atau kecakapan yang memenuhi standart mutu atau norma tertentu serta memerlukan pendidikan profesi (UU Nomor 14 Tahun 2005 Tentang Guru dan Dosen), (Kunandar, 2009,p 45).

Allah berfirman dalam Al-Qur'an, sebagai berikut:

Artinya: "Sesungguhnya Allah telah memberi karunia kepada orang yang beriman ketika Allah mengutus di antara mereka seorang Rosul dari golongan mereka sendiri yang membacakan kepada mereka ayat-ayat Allah, membersihkan jiwa mereka dan mengajarkan kepada mereka al-kitab dan al-hikmah. Dan sesungguhnya sebelum kedatangan Nabi itu, mereka benar-benar dalam kesesatan yang nyata." (QS. Ali Imran, $3: 164$ )

Kutipan ayat diatas dapat ditarik kesimpulan yang utama bahwa Rasulullah selain menjadi Nabi juga sebagai pendidik (guru). Oleh karena itu, tugas utama guru menurut ayat tersebut adalah:

1. Pensucian, yakni pengembangan, pembersihan dan pengangkatan jiwa kepada penciptanya, menjauhkan diri dari kejahatan dan menjaga diri agar tetap berada pada fitrah.

2. Pengajaran, yakni pengalihan berbagai pengetahuan serta akidah kepada akal dan hati kaum Muslimin agar mereka merealisasikannya dalam tingkah laku kehidupan.

Jadi, tugas guru dalam Islam tidak hanya mengajar dalam kelas, tetapi juga sebagai norm drager (pembawa norma) agama di tengah-tengah masyarakat. Jika manusia lahir dengan fitrah (membawa kebaikan), maka tugas pendidik harus mengembangkan elemen-elemen (kebaikan-kebaikan) tersebut yang dibawa sejak lahir. Dengan demikian, apapun yang di ajarkan di sekolah jangan sampai bertentangan dengen prinsip-prinsip fitrahnya tersebut. Oleh karena itu, kefitrahan harus tetap dikembangkan dan dilestarikan. 
Ada penyebab yang khas mengapa orang begitu terhipnotis untuk menghargai guru, yaitu karena adanya pandangan dalam Islam bahwa ilmu itu sumbernya dari Tuhan. Sebagaimana firman Allah dalam Al Qur'an:

Artinya: "tidak ada pengetahuan yang kami miliki kecuali yang engkau ajarkan kepada kami, sesungguhnys engkau yang maha mengetahui lagi maha bijaksana”. (QS Al-Baqarah, 2: 32)

Ilmu datang dari Tuhan, dengan demikian pendidik pertama adalah ketuhanan. Pandangan yang menembus langit ini dalam Islam telah melahirkan sikap bahwa ilmu itu tidak terpisah dari Allah SWT dan guru, maka wajar kalau kedudukan guru amat tinggi dalam Islam. Hubungan guru dengan anak didik dalam Islam tidak berdasarkan untung rugi. Namun, hubungan guru dengan anak didik dalam Islam adalah suatu hubungan keagamaan, suatu hubungan yang bersumber dari Allah.

Pada lazimnya pendidikan dipahami sebagai fenomena individual di satu pihak dan fenomena sosial di pihak lain. seorang guru akan terbantu jika ia memahami dan memiliki gagasan yang jelas tentang fitrah manusia. Praktek pendidikan akan menemui kegagalan kecuali jika dibangun di atas konsep yang jelas tentang fitrah manusia.

Tugas mengajar dan mendidik diumpamakan dengan sumber air. Sumber air itu mengalir dan bergabung dengan air lainnya, berpadu menjadi satu berupa sungai yang mengalir sepanjang masa. Kalau sumber air tidak diisi terus menerus, maka sumber air itu kering. Demikian juga profesi guru, jika guru tidak berusaha menambah pengetahuan yang baru melalui membaca dan terus belajar, maka materi sajian waktu mengajar akan gersang.

Oleh karena itu, ia perlu berusaha untuk tumbuh baik secara pribadi maupun secara profesi. Karenanya jabatan guru dapat diilustrasikan sebagai sumber air yang terus menerus mengalir sepanjang karir seseorang. Dan proses pertumbuhan profesi dimulai sejak guru mulai mengajar dan berlangsung sepanjang hidup dan karir. 
Adapun ciri-cirinya sebagai berikut:

a. Masyarakat mengakui bahwa profesi itu punya status yang tinggi.

b. Praktek profesi itu didasarkan pada suatu penguasaan pengetahuan yang khusus.

c. Profesi itu selalu di tantang agar orangnya memiliki keaktifan intelektual.

d. Hak untuk memiliki standar kualifikasi profesional ditetapkan dan dijamin oleh kelompok organisasi profesi. (Syaiful Bahri Djamarah, 1991, p 35)

SMA PRIMAGANDA Jombang adalah merupakan lembaga pendidikan nasional yang menanamkan IPTEK. Selain itu, IMTAQ juga ditanamkan melalui realisasi pembiasaan yang dilaksanakan setiap hari, seperti membaca beberapa surat dari al-Qur'an, Asma'ul Husna, serta berdo'a bersama sebelum dan sesudah pelaksanaan kegiatan belajar mengajar. Tidak hanya itu, di setiap malam ahad legi seluruh peserta didik Muslim dibiasakan untuk mengikuti shalat-shalat sunnah, pembacaan istighosah dan dilanjutkan dengan tadarrus atau Khotmil Qur'an.

Keikutsertaan guru PAI sangat berpengaruh dalam pembiasaan tersebut. Karena profesi guru PAI harus bisa dijadikan panutan peserta didik. Tugas utama guru PAI adalah memperbaiki akhlak atau moral, serta menanamkan keimanan dan ketaqwaan dalam hati sanubari peserta didik. Itulah yang menjadi alasan utama bagi peneliti untuk melakukan penelitian di SMA PRIMAGANDA Jombang. Karena profesi guru sangatlah luas, tidak hanya di lingkup sekolah, tapi juga harus siap berprofesi guru di luar sekolah, khususnya pendidik moral atau guru PAI. Tujuan dari penelitian ini juga untuk mengetahui kelayakan profesi guru untuk digugu dan ditiru.

\section{Pembahasan}

\section{Pengembangan Profesionalitas Guru PAI}

\section{a. Pengertian Pengembangan Profesionalitas Guru PAI}

Pendidikan merupakan interaksi antara orang dewasa dengan orang yang belum dapat menunjang perkembangan manusia yang berorientasikan pada nilai-nilai dan pelestarian serta perkembangan kebudayaan yang berhubungan dengan usaha pengembangan kehidupan manusia (H. Gunawan, 1906, p 1). 
Seperti yang kita ketahui sehari-hari guru merupakan orang yang harus digugu dan ditiru. Guru adalah orang yang memiliki charisma atau wibawa hingga perlu untruk ditiru dan diteladani. Guru adalah orang dewasa yang secara sadar bertanggung jawab dalam mendidik, mengajar dan membimbing peserta didik. Orang yang disebut guru adalah orang yang memiliki kemampuan merancang program pembelajaran serta mampu menata dan mengelola kelas agar peserta didik dapat belajar dan pada akhirnya dapat mencapai tingkat kedewasaan sebagai tujuan akhir dari proses pendidikan (Umi Machmudah dan Abdul Wahab Rosyidi, 2008,p 10).

Guru dalam literatur kependidikan Islam biasa disebut dengan ustadz, mu'allim, murabby, mursyid, mudaris, dan mu'addib, yang mana seorang guru dituntut komitmen terhadap profesionalitas dalam mengemban tugasnya (Muhaimin, 2003,p .209). Profesional disini adalah bilamana dalam dirinya melekat sikap dedikatif yang tinggi terhadap tugasnya, sikap komitmen terhadap mutu proses dan hasil kerja dan sikap selalu berusaha memperbaiki dan memperbaharui model-model atau cara kerjanya sesuai dengan tuntutan zaman, yang dilandasi dengan kesadaran tinggi bahwa tugas mendidik adalah tugas menyiapkan generasi penerus (Muhaimin, 2003,p .209)

.Guru merupakan salah satu faktor utama dalam menentukan keberhasilan mutu pendidikan. Gurulah yang berada di garda terdepan dalam menciptakan kualitas sumber daya manusia. Ditangan gurulah akan dihasilkan peserta didik yang berkualitas baik secara akademik, skill (keahlian), kematangan emosional, dan moral serta spiritual. Dengan demikian akan dihasilkan generasi masa depan yang siap hidup dengan tantangan zamannya.

Proses belajar mengajar merupakan inti dari proses pendidikan secara keseluruhan dengan guru sebagai pemegang peranan utama. Proses belajar mengajar merupakan suatu proses yang mengandung serangkaian perbuatan guru dan siswa atas dasar hubungan timbal balik yang berlangsung edukatif untuk mencapai tujuan tertentu (Muhamad Nurdin, 2004, p. 4). Guru sebagai jabatan profesional memegang peranan utama dalam proses pendidikan secara 
keseluruhan. Mengajar adalah membimbing aktivitas belajar siswa, agar bisa menjadi efektif dan dapat mencapai hasil yang optimal.

Untuk pengembangan profesionalitas, diperlukan KASAH. Oleh karena itu didalam pembahasan masalah pengembangan profesionalitas tidak akan terlepas dari kata kunci tersebut yaitu:

1) Knowledge (pengetahuan)

Yaitu sesuatu yang didapat dari membaca dan pengalaman. Sedangkan ilmu pengetahuan adalah pengetahuan yang didapat dengan jalan keterangan (analisis). Jadi pengetahuan adalah sesuatu yang bisa dibaca, di pelajari dan dialami oleh setiap orang. Namun, pengetahuan seseorang harus diuji terlebih dahulu melalui penerapan di lapangan.

Penerapan pengetahuan tergantung pada wawasan, kepribadian, kepekaan seseorang dalam melihat situasi dan kondisi. Dalam mengembangkan profesionalisme guru, menambah ilmu pengetahuan adalah hal yang mutlak. Guru harus mempelajari segala macam pengetahuan, akan tetapi Guru juga harus mengadakan skala prioritas. Karena menunjang keprofesionalan sebagai guru, menambah ilmu pengetahuan tentang keguruan sangat perlu. Semakin banyak ilmu pengetahuan yang dipelajari semakin banyak pula wawasan yang di dapat tentang ilmu.

2) Ability (kemampuan)

Terdiri dua unsur, yaitu yang bisa dipelajari dan yang alamiah. Pengetahuan dan keterampilan adalah unsur kemampuan yang bisa dipelajari sedangkan yang alamiah orang menyebutnya dengan bakat. Jika hanya mengandalkan bakat saja tanpa mempelajari dan membiasakan kemampuannya, maka dia tidak akan berkembang. Karena bakat hanya sekian persen saja menuju keberhasilan, dan orang yang berhasil dalam pengembangan profesionalisme itu ditunjang oleh ketekunan dalam mempelajari dan mengasah kemampuannya. Oleh karena itu potensi yang ada pada setiap pribadi khususnya seroang guru harus terus diasah.

Seorang guru yang mempunyai kemampuan tinggi akan selalu memperhitungkan segala sesuatunya, yaitu seberapa besar kemampuan bisa menghasilkan prestasi profesionalisme di dapat dari unsur kemauan dan kemampuan. Kemampuan paling dasar yang diperlukan adalah kemampuan dalam mengantisipasi setiap perubahan yang terjadi. Oleh karena itu, seorang guru yang profesional tentunya tidak ingin ketinggalan dalam percaturan global.

3) Skill (keterampilan)

Keterampilan merupakan salah satu unsur kemampuan yang dapat dipelajari pada unsur penerapannya. Keterampilan juga merupakan keahlian yang bermanfaat untuk jangka panjang. Banyak sekali keterampilan yang dibutuhkan dalam pengembangan profesionelisme, tergantung pada jenis pekerjaan masing-masing. Keterampilan mengajar 
merupakan pengetahuan dan kemampuan yang diperlukan untuk melaksanakan tugas guru dalam pengajaran.

Bagi seorang guru yang tugasnya mengajar dan peranannya di dalam kelas, keterampilan yang harus dimilikinya adalah guru sebagai pengajar, guru sebagai pemimpin kelas, guru sebagai pembimbing, guru sebagai pengatur lingkungan, guru sebagai partisipan, guru sebagai ekspeditur, guru sebagai perencana, guru sebagai supervisor, guru sebagai motivator, guru sebagai penanya, guru sebagai pengajar, guru sebagai evaluator dan sebagai konselor.

4) Attitude (sikap diri)

Sikap diri seseorang terbentuk oleh suasana lingkungan yang mengitarinya. Oleh karenanya sikap diri perlu dikembangkan dengan baik. Kepribadian menyangkut keseluruhan apsek seseorang baik fisik maupun psikis dan dibawa sejak lahir maupun yang diperoleh dari pengalaman.

Kepribadian bukan terjadi dengan tiba-tiba akan tetapi terbentuk melalui perjuangan hidup yang sangat panjang. Karena kepribadian adalah dinamis maka dalam proses kehidupan yang dijalani oleh setiap manusia pun berbeda-beda. Usaha yang sistematis dan terencana sesuai dengan tujuan akhir pendidikan peran guru sangat menentukan kepribadian peran guru.

5) Habit (kebiasaan diri)

Yaitu suatu kegiatan yang terus menerus dilakukan yang tumbuh dari dalam pikiran. Pengembangan kebiasaan diri harus dilandasi dengan kesadaran bahwa usaha tersebut memutuhkan proses yang cukup panjang. Kebiasaan positif diantaranya adalah menyapa dengan ramah, memberikan rasa simpati, menyampaikan rasa penghargaan kepada kerabat, teman sejawat atau anak didik yang berprestasi dan lain-lain. (Cece Wijaya, Tabrani Rusyan, 2000,p 11)

Kutipan diatas mengisyaratkan bahwa persoalan pendidikan adalah bagaimana memberikan suasana yang kondusif bagi pengembangan etos kultural manusia, sehingga dalam kehidupan riil dapat melakukan dialog dengan lingkungan sekitar. Oleh sebab itu, pendidikan harus berperan dalam hal pengembangan potensi yang dikandung manusia tersebut. (Soebagio Atmodiworio, 2000,p. 202)

Kondisi belajar mengajar yang efektif adalah adanya minat dan perhatian siswa dalam belajar. Bakat yang terdapat dalam diri seseorang merupakan suatu sifat yang relatif menetap. Dengan adanya pengembangan terhadap profesi guru diharapkan dapat membangkitkan minat anak terhadap belajar. Karena tugas guru adalah membangkitkan motifasi anak sehingga ia 
mau melakukan belajar. Motifasi dapat timbul dari dalam diri individu dan dapat pula timbul akibat pengaruh dari luar dirinya.

Motifasi berasal dari kata dasar motif, yaitu daya dalam diri seseorang yang mendorongnya untuk melakukan sesuatu atau organisme (keadaan seseorang) yang menyebabkan kesiapannya untuk memulai serangkaian tingkah laku atau perbuatan. Dalam artian lain, motifasi adalah proses menggiatkan tingkah laku untuk memenuhi kebutuhan dan mencapai tujuan atau keadaan dan kesiapan dalam diri individu yang mendorong tingkah lakunya untuk berbuat sesuatu dalam mencapai tujuan tertentu. (Piet A. Sahertian, 1999,p.29)

b. Pengertian Profesi Guru

Profesi pada hakikatnya adalah suatu pernyataan atau suatu janji terbuka yang menyatakan bahwa seseorang itu mengabdikan dirinya pada suatu jabatan atau pelayanan, karena orang tersebut merasa terpanggil untuk menjabat pekerjaan itu. Istilah profesi merupakan simbol dari suatu pekerjaan dan selanjutnya menjadi pekerjaan itu sendiri. (Piet A. Sahertian, 1999,p.29) Menurut Chandler yang dialih bahasakan oleh Piet A. Sahertian menegaskan bahwa:

"Profesi mengajar adalah suatu jabatan yang mempunyai kekhususan. Kekhususan itu memerlukan kelengkapan mengajar dan atau keterampilan yang menggambarkan bahwa seseorang melakukan tugas mengajar yaitu membimbing manusia”. (Piet A. Sahertian, 1999,p.29)

Guru adalah suatu profesi yang menunjukkan bahwa orang itu lebih mementingkan layanan kemanusiaan dari pada kepentingan pribadi. Adapun ciri-ciri guru profesional sebagai berikut:

1) Memiliki kemampuan sebagai ahli dalam bidang mendidik dan mengajar.

2) Memiliki rasa tanggung jawab, yaitu mempunyai komitmen dan kepedulian terhadap tugasnya.

3) Memiliki rasa kesejawatan dan menghayati tugasnya sebagai suatu karier hidup serta menjunjung tinggi kode etik jabatan guru. (Piet A. Sahertian, 2002, p.2) 
Selain ciri-ciri di atas, adapun macam-macam kompetensi yang harus dimiliki oleh seorang guru antara lain: kompetensi pedagogik, kepribadian, profesional dan sosial yang diperoleh melalui pendidikan profesi. Keempat kompetensi tersebut terintegrasi dalam kinerja seorang guru.

1) Kompetensi Pedagogik

Kompetensi pedagogik meliputi pemahaman guru terhadap peserta didik, perancangan dan pelaksanaan pembelajaran, evaluasi hasil belajar, dan pengembangan peserta didik untuk mengaktualisasikan berbagai potensi yang dimilikinya. Secara rinci setiap subkompetensi dijabarkan menjadi indikator esensial sebagai berikut:

a) Memahami peserta didik secara mendalam memiliki indikator esensial: memahami peserta didik dengan memanfaatkan prinsip- prinsip perkembangan kognitif; memahami peserta didik dengan memanfaatkan prinsip-prinsip kepribadian; dan mengidentifikasi bekal ajar awal peserta didik.

b) Merancang pembelajaran, termasuk memahami landasan pendidikan untuk kepentingan pembelajaran memiliki indikator esensial: memahami landasan kependidikan; menerapkan teori belajar dan pembelajaran; menentukan strategi pembelajaran berdasarkan karakteristik peserta didik, kompetensi yang ingin dicapai, dan materi ajar; serta menyusun rancangan pembelajaran berdasarkan strategi yang dipilih.

c) Melaksanakan pembelajaran memiliki indikator esensial: menata latar (setting) pembelajaran; dan melaksanakan pembelajaran yang kondusif.

d) Merancang dan melaksanakan evaluasi pembelajaran memiliki indikator esensial: merancang dan melaksanakan evaluasi (assessment) proses dan hasil belajar secara berkesinambungan dengan berbagai metode; menganalisis hasil evaluasi proses dan hasil belajar untuk menentukan tingkat ketuntasan belajar (mastery 
learning); dan memanfaatkan hasil penilaian pembelajaran untuk perbaikan kualitas program pembelajaran secara umum.

e) Mengembangkan peserta didik untuk mengaktualisasikan berbagai potensinya, memiliki indikator esensial: memfasilitasi peserta didik untuk pengembangan berbagai potensi akademik; dan memfasilitasi peserta didik untuk mengembangkan berbagai potensi nonakademik.

2) Kompetensi Kepribadian

Kompetensi kepribadian merupakan kemampuan personal yang mencerminkan kepribadian yang mantap, stabil, dewasa, arif, dan berwibawa, menjadi teladan bagi peserta didik, dan berakhlak mulia. Secara rinci subkompetensi tersebut dapat dijabarkan sebagai berikut:

a) Kepribadian yang mantap dan stabil memiliki indikator esensial: bertindak sesuai dengan norma hukum; bertindak sesuai dengan norma sosial; bangga sebagai guru; dan memiliki konsistensi dalam bertindak sesuai dengan norma.

b) Kepribadian yang dewasa memiliki indikator esensial: menampilkan kemandirian dalam bertindak sebagai pendidik dan memiliki etos kerja sebagai guru.

c) Kepribadian yang arif memiliki indikator esensial: menampilkan tindakan yang didasarkan pada kemanfaatan peserta didik, sekolah, dan masyarakat serta menunjukkan keterbukaan dalam berpikir dan bertindak.

d) Kepribadian yang berwibawa memiliki indikator esensial: memiliki perilaku yang berpengaruh positif terhadap peserta didik dan memiliki perilaku yang disegani.

e) Akhlak mulia dan dapat menjadi teladan memiliki indikator esensial: bertindak sesuai dengan norma religius (iman dan taqwa, jujur, ikhlas, suka menolong), dan memiliki perilaku yang diteladani peserta didik.

3) Kompetensi Profesional

Kompetensi profesional merupakan penguasaan materi pembelajaran secara luas dan mendalam, yang mencakup penguasaan materi kurikulum 
mata pelajaran di sekolah dan substansi keilmuan yang menaungi materinya, serta penguasaan terhadap stuktur dan metodologi keilmuannya. Setiap subkompetensi tersebut memiliki indikator esensial sebagai berikut:

a) Menguasai substansi keilmuan yang terkait dengan bidang studi memiliki indikator esensial: memahami materi ajar yang ada dalam kurikulum sekolah; memahami struktur, konsep dan metode keilmuan yang menaungi atau koheren dengan materi ajar; memahami hubungan konsep antar mata pelajaran terkait; dan menerapkan konsep-konsep keilmuan dalam kehidupan sehari-hari.

b) Menguasai struktur dan metode keilmuan memiliki indikator esensial menguasai langkah-langkah penelitian dan kajian kritis untuk memperdalam pengetahuan/materi bidang studi.

4) Kompetensi Sosial

Kompetensi sosial merupakan kemampuan guru untuk berkomunikasi dan bergaul secara efektif dengan peserta didik, sesama pendidik, tenaga kependidikan, orang tua/wali peserta didik, dan masyarakat sekitar. Kompetensi ini memiliki sub kompetensi dengan indikator esensial sebagai berikut:

a) Mampu berkomunikasi dan bergaul secara efektif dengan peserta didik memiliki indikator esensial: berkomunikasi secara efektif dengan peserta didik.

b) Mampu berkomunikasi dan bergaul secara efektif dengan sesama pendidik dan tenaga kependidikan.

c) Mampu berkomunikasi dan bergaul secara efektif dengan orang tua/wali peserta didik dan masyarakat sekitar.

Keempat kompetensi tersebut di atas bersifat holistik dan integratif dalam kinerja guru. Oleh karena itu, secara utuh sosok kompetensi guru meliputi: (a) Pengenalan peserta didik secara mendalam; (b) Penguasaan bidang studi baik disiplin ilmu (disciplinary content) maupun bahan ajar dalam kurikulum sekolah; (c) Penyelenggaraan pembelajaran yang 
mendidik meliputi perencanaan dan pelaksanaan pembelajaran, evaluasi proses dan hasil belajar, serta tindak lanjut untuk perbaikan dan pengayaan; (d) Pengembangan kepribadian dan profesionalitas secara berkelanjutan; Guru yang memiliki kompetensi akan dapat melaksanakan tugasnya secara profesional.

Berdasarkan peraturan menteri agama Republik Indonesia No. 16 Tahun 2010 di atas, bahwa salah satu kompetensi guru agama Islam tidak hanya ditentukan oleh kompetensi pedagogik, sosial, kepribadian dan profesional saja, akan tetapi dituntut juga memiliki kompetensi kepemimpinan (leadership). Berbeda dengan guru mata pelajaran biasa atau non guru agama Islam (Hari Santoso, 2010,p.57).

Meskipun demikian dalam pengamatan peneliti sebagai praktisi pendidikan belum banyak guru agama Islam yang menyadari akan kompetensi kepemimpinan tersebut. Mereka menganggap bahwa kompetensi kepemimpinan itu hanya milik kepala sekolah/madrasah atau para wakilwakil kepala yang duduk dalam jajaran pejabat struktural madrasah. Dengan pemahaman seperti ini kemudian mereka memposisikan sebagai guru biasa atau sama dengan guru mata pelajaran umum (non agama). Hal ini terlihat, ketika mereka dalam menyusun administrasi ataupun dalam kinerja harian dalam melaksanakan tugas dan tanggung jawabnya sebagai guru agama Islamdi sekolah atau madrasah yang menjadi tempat bertugas.

5) Kompetensi Kepemimpinan (leadership)

Yaitu kemampuan sebagai pemimpin informal yang berkaitan dengan peran guru PAI yang tidak hanya di kelas, tetapi juga mempengaruhi seluruh warga sekolah dalam pengembangan budaya agama di sekolah. Kompetensi kepemimpinan sebagaimana dimaksud meliputi:

a) Kemampuan membuat perencanaan pembudayaan pengamalan ajaran agama dan perilaku akhlak mulia pada komunitas sekolah sebagai bagian dari proses pembelajaran agama 
b) Kemampuan mengorganisasikan potensi unsur sekolah secara sistematis untuk mendukung pembudayaan pengamalan ajaran agama pada komunitas sekolah;

c) Kemampuan menjadi inovator, motivator, fasilitator, pembimbing dan konselor dalam pembudayaan pengamalan ajaran agama pada komunitas sekolah; serta

d) Kemampuan menjaga, mengendalikan, dan mengarahkan pembudayaan pengamalan ajaran agama pada komunitas sekolah dan menjaga keharmonisan hubungan antar pemeluk agama dalam bingkai Negara Kesatuan Republik Indonesia.

Ada beberapa alasan mengapa kompetensi kepemimpinan (leadership) itu penting bagi guru agama, antara lain:

a) Guru agama bukanlah guru biasa.

Guru agama harus bisa menjadi contoh dan teladan bagi peserta didik dan juga teman-teman sejawat. Dengan kompetensi ini diharapkan guru agama tersebut merasa bahwa dirinya sebagai pemimpin bagi orang lain maka ia akan memberikan contoh yang terbaik bagi lingkungannya, sekurangkurangnya adalah pemimpin bagi dirinya dengan berpegang pada prinsip “ibda' binafsih”.

b) Guru agama diharapkan dapat memberikan pelayanan lebih kepada peserta didik.

Guru agama harus mampu membuat perubahan pada kondisi peserta didikdari uncredible source menjadi credible source.Di sinilah peran sebagai guru yang memiliki jiwa pemimpin sanggup memberi dampak yang lebih besar bagi kepentingan terbaik siswa, keep growing, keep leading and keep to make differences. Jika siswa saat ini makin kaya pengetahuan, makin berdaya dan makin kritis guru biasa munkin saja cuek atau mudah marah 3 menghadapi aneka perilaku unik siswa bersangkutan tapi guru agama bisa menjadi sosok yang dipercaya siswa untuk "curhat" dan sebagainya. 
c) Guru agama diharapkan mampu membangkitkan kesadaran berprestasi siswanya. (M.H. Matondang, 2010,p.14)

Guru tidak hanya dipandang oleh siswa sebagai guru yang hanya menjalankan tugas mengajar saja melainkan juga sebagai "coach" atau pelatih yang bisa memotivasi untuk melejitkan potensi yang dimilikisiswa. Yaitu dengan cara menempatkan dirinya sebagai sumber inspirasi (insipiration source) bagi siswanya. Guru yang memiliki jiwa kepemimpinan akan terus mengembangkan lingkungan pembelajaran yang kondusif untuk pengembangan prestasi siswa. Dia juga sebagai pembelajar seumur hidup "life long learning".

Pengembangan kelima kompetensi tersebut, lanjutnya, untuk memenuhi amanat Peraturan Pemerintah Nomor 55 Tahun 2007 tentang Pendidikan Agama dan Pendidikan Keagamaan. Hal ini perlu terus dilakukan baik melalui pendidikan dan pelatihan, workshop, dan kerja kelompok atau organisasi profesi guru seperti MGMP PAI Kabupaten Jombang.

Seorang guru dikatakan profesional bila guru memiliki kualitas mengajar yang tinggi. Padahal profesional mengandung makna yang lebih luas dari hanya berkualitas tinggi dalam hal teknis. Guru bukan hanya pengajar, tetapi juga pendidik. Melalui pengajaran guru membentuk konsep berpikir, sikap jiwa dan menyentuh afeksi yang terdalam dari inti kemanusiaan subjek didik. (A. Samana, 1994,p.101)

Guru berfungsi sebagai pemberi inspirasi. Guru menolong subjek didik agar dapat menolong dirinya sendiri. Guru menumbuhkan prakarsa dan motivasi agar subjek didik dapat mengaktualisasikan dirinya sendiri. Jadi, guru yang ahli mampu menciptakan situasi belajar yang mengandung makna relasi interpersonal, yaitu mampu membuat subjek didik merasa "diorangkan" dan mempunyai jati diri.

Dunia pendidikan dewasa ini berkembang semakin pesat dan semakin kompleksnya persoalan pendidikan yang dihadapi bukanlah tantangan yang dibiarkan begitu saja, tetapi memerlukan pemikiran yang konstruktif demi 
tercapainya kualitas yang baik. Persoalan yang dimaksud diantaranya adalah kompetensi mengajar guru. Karena guru sebagai tenaga pendidik yang paling banyak berhubungan dengan peserta didik diharuskan mempunyai kompetensi yang baik dalam pelaksanaan kegiatan pembelajaran. (Raflis Kosasi, 1999,p. 46)

Sehubungan dengan hal tersebut Ametembun seperti yang dikutip oleh Syaiful Bahri Djamarah menyatakan bahwa :

"Guru sebagai orang yang berwenang dan bertanggung jawab terhadap pendidikan siswa, baik secara individual maupun secara klasikal baik di sekolah maupun di luar sekolah minimal harus memiliki dasar-dasar kompetensi sebagai wewenang dalam menjalankan tugasnya." (Syaiful Bahri Djamarah, 1991,p.33)

Untuk itu seorang guru perlu memiliki kepribadian, menguasai bahan pelajaran dan menguasai cara-cara mengajar sebagai kompetensinya. Tanpa hal tersebut guru akan gagal dalam melaksanakan tugasnya. Karena kompetensi mengajar harus dimilki oleh seorang guru yang merupakan kecakapan atau keterampilan dalam mengelola kegiatan pendidikan.

Dalam rangka peningkatan mutu pendidikan, guru mempunyai peranan yang sangat penting dalam merealisasikan tujuan pendidikan nasional. Guru lah ujung tombak kegiatan pengajaran di sekolah yang langsung berhadapan dengan peserta didik. Tanpa adanya peranan guru maka kegiatan belajar mengajar tidak bisa berjalan dengan semestinya.Seorang guru seharusnya memiliki pemahaman-pemahaman yang dalam tentang pengajaran.

Mengajar bukanlah kegiatan yang mudah melainkan suatu kegiatan dan tugas yang berat dan penuh dengan permasalahan. Kemampuan dan kecakapan sangat dituntut bagi seorang guru. Karena itu seorang guru harus memilki kecakapan dan keahlian tentang keguruan. Kemampuan dan kecakapan merupakan modal dasar bagi seorang guru dalam melakukan kegiatan atau tugasnya. Mengajar adalah membimbing kegiatan siswa, mengatur dan mengorganisasikan lingkungan yang ada disekitar siswa 
sehingga dapat mendorong dan menumbuhkan semangat siswa untuk melakukan kegiatan belajar.

Penelitian yang dilakukan penulis adalah tentang profesi guru PAI. Pengertian guru sebagaimana telah disinggung diatas bahwa secara implisit ia telah merelakan dirinya menerima sebagian tanggung jawab pendidikan yang menjadi tanggung jawab para orang tua. Dengan demikian, dapat disimpulkan bahwa guru secara umum dapat memberikan sebuah tanggung jawab kepada anak didiknya melalui ilmu secara umum. Kemudian guru agama Islam lebih khusus kepada ilmu secara khusus, yaitu memberikan pengajaran secara formil kepada anak didiknya untuk mempelajari ilmu agama Islam dalam jangka waktu tertentu dengan kurikulum dan metode yang telah disiapkan.

Hakikat manusia adalah sebagai pribadi yang utuh, yang mampu menentukan diri sendiri atas tanggung jawab sendiri. Guru yang ahli harus dapat menyentuh inti kemanusiaan subjek didik melalui pelajaran yang diberikan. Ini berarti bahwa cara mengajar guru harus diubah dengan cara yang bersifat dialogis dalam arti yang ekstensial. Jadi jabatan guru di samping sebagai pengajar, pembimbing dan pelatih pula dipertegas sebagai pendidik.

Guru dibentuk bukan hanya untuk memiliki seperangkat keterampilan teknis saja, tetapi juga memiliki kiat mendidik serta sikap yang profesional. Dengan demikian praktek pengalaman calon guru harus lebih lama sekurangkurangnya satu tahun agar mereka memperoleh peningkatan dan kelengkapan profesional yang mantap sebelum terjun dalam dunia mengajar.

Guru yang profesional di samping ahli dalam bidang mengajar dan mendidik, ia juga memiliki otonomi dan tanggung jawab. Yang dimaksud dengan otonomi adalah suatu sikap yang profesional yang disebut mandiri. Ia telah memiliki otonomi atau kemandirian yang dalam mengemukakan apa yang harus dikatakan berdasarkan keahliannya. Pada awalnya ia belum punya kebebasan atau otonomi. Ia masih belajar magang. Melalui proses 
belajar dan perkembangan profesi, maka pada suatu saat ia akan memiliki sikap mandiri. (Syafruddin Nurdin, 2002,p. 24)

Pengertian bertanggung jawab menurut teori ilmu mendidik mengandung arti bahwa seseorang mampu memberi pertanggung jawaban dan bersedia untuk dimintai pertanggung jawaban. Tanggung jawab yang mengandung makna multidimensional ini berarti bertanggung jawab terhadap diri sendiri, terhadap siswa, terhadap orang tua, lingkungan sekitarnya, masyarakat, bangsa dan negara, serta sesama manusia dan akhirnya terhadap Tuhan Yang Maha Pencipta. (Amier Daien Indrakusuma, 1999),p. 34)

Pada dasarnya profesionalisasi guru PAI merupakan suatu proses berkesinambungan melalui berbagai program pendidikan, baik pendidikan prajabatan (preservice training) maupun pendidikan dalam jabatan (inservice training) agar para guru PAI benar-benar memiliki profesionalitas yang standar. Untuk mendapatkan derajat profesionalitas yang diidamkan oleh para guru PAI, harus terpenuhi standar kualifikasi, standar kompetensi dan sertifikasi. (Tim Instruktur, 2011,p. 7)

a. Standar Kualifikasi Guru PAI

Standar kualifikasi guru PAI mengarah pada jenjang pendidikan minimal S1/D-IV jurusan PAI PTAI yang terkreditasi.

b. Standar Kompetensi Guru PAI

Kompetensi guru sebagaimana dimaksud pada ayat (1) PP 74/2008 meliputi kompetensi pedagogik, kompetensi kepribadian, kompetensi sosial, dan kompetensi profesional yang diperoleh melalui pendidikan profesi. Empat kompetensi guru tersebut bersifat holistik, artinya merupakan satu kesatuan utuh yang saling terkait.

c. Sertifikasi Guru PAI

Sertifikasi adalah proses pemberian sertifikat pendidik bagi guru/calon guru yang telah memenuhi persyaratan dan lulus uji kompetensi.

Guru sebagai sosial worker (pekerja sosial) sangat dibutuhkan oleh masyarakat. Namun kebutuhan masyarakat akan guru belum seimbang 
dengan sikap sosial masyarakat terhadap profesi guru. Rendahnya pengakuan masyarakat terhadap guru disebabkan oleh beberapa faktor yaitu: (Hasbullah, 1999, p. 192)

a. Adanya pandangan sebagian masyarakat bahwa siapapun dapat menjadi guru, asalkan ia berpengetahuan, walaupun tidak mengerti didaktik metodik.

b. Kekurangan tenaga guru di daerah terpencil memberikan peluang untuk mengangkat seseorang yang tidak mempunyai kewenangan profesional untuk menjadi guru.

c. Banyak tenaga guru yang belum bisa menghargai profesinya sendiri. Perasaan rendah diri menjadi guru masih mengelayut di hati mereka, sehingga menjadikan pudarnya wibawa guru dimata masyarakat.

Salah satu hal menarik pada ajaran Islam adalah penghargaan yang tinggi terhadap guru. Begitu tingginya penghargaan ini sehingga menempatkan kedudukan guru setingkat di bawah kedudukan Nabi dan Rosul. Mengapa demikian, karena guru adalah bapak rohani (spiritual father) bagi anak didik yang memberi santapan jiwa dengan ilmu pengetahuan. (Barni Mahyuddin, 2011,p.18)

Penghargaan Islam terhadap orang yang berilmu tergambar dalam hadist seperti dikutip oleh Ahmad Tafsir, yaitu :

a. Tinta ulama' lebih berharga dari pada darah para syuhada.

b. Orang yang berpengetahuan melebihi orang yang senang beribadah, orang yang berpuasa, dan orang yang berjuang di jalan Allah.

c. Apabila meninggal seorang alim maka terjadilah kekosongan dalam Islam yang tidak dapat diisi kecuali oleh orang yang alim pula. (Barni Mahyuddin, 2011,p.18)

Guru merupakan faktor yang sangat dominan dan paling penting dalam pendidikan formal pada umumnya, karena bagi siswa guru sering dijadikan tokoh teladan bahkan menjadi tokoh identifikasi diri. Oleh sebab itu guru seyogyanya memiliki perilaku dan kemampuan yang memadai untuk mengembangkan siswanya secara utuh. Untuk melaksanakan 
tugasnya secara baik sesuai dengan profesi yang dimilikinya guru perlu menguasai berbagai hal sebagai kompetensi yang dimilikinya.

Guru harus memahami dan menghayati para siswa yang dibinanya, karena wujud siswa pada setiap saat tidak akan sama. Sebab perkembangan ilmu pengetahuan dan teknologi yang memberikan dampak serta nilai-nilai budaya masyarakat Indonesia sangat mempengaruhi gambaran para lulusan suatu sekolah yang diharapkan. Oleh sebab itu, guru diharapkan mampu mengantisipasi perkembangan keadaaan dan tuntutan masyarakat pada masa yang akan datang. (Hamzah Uno B, 2010, p.21)

c. Syarat-syarat menjadi guru professional

Salah satu kemajuan zaman adalah adanya suatu pekerjaan yang ditangani secara profesionalis, sehingga pekerjaan itu dikerjakan secara sungguh-sungguh dan serius. Pekerjaan guru merupakan profesi, karena itu harus dikerjakan sesuai dengan tuntutan profesi. (Haidar Putra Daulay, 2006, p. 76.)

Dibidang guru ada tiga persyaratan pokok seseorang itu menjadi tenaga professional dibidang keguruan. Pertama, memiliki ilmu pengetahuan di bidang yang diajarkannya sesuai dengan kualifikasi dimana dia mengajar. Kedua, memiliki pengetahuan dan keterampilan dibidang keguruan, dan ketiga memilki moral akademik.

Profesional adalah pekerjaan atau kegiatan yang dilakukan oleh seseorang dan menjadi sumber penghasilan kehidupan yang memerlukan keahlian, kemahiran atau kecakapan yang memenuhi standart mutu atau norma tertentu serta memerlukan pendidikan profesi (UU Nomor 14 Tahun 2005 Tentang Guru dan Dosen). (Kunandar, 2009,p.45)

\section{d. Ciri-ciri Guru PAI Profesional}

Moore mengidentifikasikan profesi menurut cirri-ciri berikut:

1. Seseorang professional menggunakan waktu penuh untuk menjalankan pekerjaannya

2. Ia terikat oleh panggilan hidup dan dalam hal ini memperlakukan pekerjaannya sebagai perangkat norma kepatuhan dan perilaku

3. Ia anggota organisasi professional yang formal 
4. Ia menguasai pengetahuan yang berguna dan keterampilan atas dasar latihan spesialisasi atau pendidikan yang sangat khusus

5. Ia terikat dengan syarat-syarat kompetensi, kesadaran prestasi dan pengabdian

6. Ia memperoleh otonomi berdasarkan spesialisasi teknis yang tinggi sekali(Martinis Yamin, 2008,p.14.)

\section{Bentuk-bentuk Pengembangan Profesionalitas Guru PAI di SMA PRIMAGANDA Jombang}

Berbicara tentang perbaikan kinerja guru atau pengembangan profesionalitas khususnya Guru PAI, tidak bisa dilepaskan dari tugas pokok (tupoksi) utama dan berbagai tanggung jawab guru yang terkait lainnya. Tugas dan tanggung jawab guru meliputi banyak hal, yaitu guru dapat berperan sebagai pengajar, pemimpin kelas, pembimbing, pengatur lingkungan belajar, perencana pembelajaran, supervisor, motivator, evaluator, inovator, serta tugas lainnya yang terkait dengan statusnya sebagai guru pendidikan agama Islam.

Guru harus memiliki karakteristik profesional. Pertama, komitmen terhadap profesionalitas yang melekat pada dirinya sikap dedikatif, komitmen terhadap mutu proses dan hasil kerja (produk), dan sikap continous improvement (improvisasi berkelanjutan). Kedua, menguasai dan mampu mengembangkan serta menjelaskan fungsi ilmu dalam kehidupan, mampu menjelaskan dimensi teoretis dan praktisnya. Dengan kata lain, mampu melakukan transformasi, internalisasi, dan implementasi ilmu kepada peserta didik. Ketiga, mendidik dan menyiapkan peserta didik yang memiliki kemampuan berkreasi, mengatur dan memelihara hasil kreasinya supaya tidak menimbulkan malapetaka bagi dirinya, masyarakat, dan lingkungannya. Keempat, mampu menjadikan dirinya sebagi model dan pusat anutan (centre of selfidentification), teladan, dan konsultan bagi peserta didiknya. Kelima, mampu bertanggung jawab dalam membangun peradaban di masa depan (civilization of the future). Untuk memenuhi tuntutan kinerja guru yang baik, maka pembinaan profesionalisme guru menjadi sebuah keniscayaan. Ketika hal ini dihindari atau tidak dijalankan maka peningkatan mutu pendidikan yang diharapkan tidak akan pernah terwujud. 
Kedudukan dan posisi guru sebagai tenaga profesional bertujuan untuk melaksanakan sistem pendidikan nasional dan sekaligus mewujudkan tujuannya. Untuk mencapai kreteria profesional, guru harus menjalani profesionalisasi atau proses menuju derajat profesional yang sesungguhnya secara terus menerus, termasuk kompetensi mengelola kelas. Berdasarkan UU Nomor 74 Tahuan 2008 dibedakan antara pembinaan dan pengembangan profesionalitas guru yang belum dan yang sudah berkulifikasi S-1 atau D-IV.

Pengembangan dan peningkatan kompetensi bagi guru yang sudah memiliki sertifikat pendidik dilakukan dalam rangka menjaga agar kompetensi keprofesiannya tetap sesuai dengan perkembangan ilmu pengetahuan, teknologi, seni, budaya, dan atau olah raga. Pembinaan dan pengembangan profesi dan karir guru (P3KG) meliputi pembinaan kompetensi pedagogik, kompetensi kepribadian, kompetensi sosial, dan kompetensi profesional.

Pembinaan dan pengembangan karir meliputi penugasan, kenaikan pangkat, dan promosi. Upaya pembinaan dan pengembangan karir ini harus sejalan dengan jenjang jabatan fungsional para guru. Kegiatan pembinaan dan pengembangan ini bisa dijalankan melalui prakarsa pemerintah, pemerintah daerah, penyelenggara pendidikan, asosiasi guru, juga bisa melalui inisiatif guru itu sendiri.

Pada dasarnya profesionalisasi guru PAI merupakan suatu proses berkesinambungan melalui berbagai program pendidikan, baik pendidikan prajabatan (preservice training) maupun pendidikan dalam jabatan (in-service training) agar para guru PAI benar-benar memiliki profesionalitas yang standar. Untuk mendapatkan derajat profesionalitas yang diidamkan oleh para guru PAI, harus terpenuhi standar kualifikasi, standar kompetensi dan sertifikasi. (Tim Instruktur, 2011,p.7) Oleh karena itu pendidikan, pelatihan, dan pengembangan profesionalitas merupakan proses yang harus ditempuh para guru pada saat menjalani tugas-tugas kedinasan. Kegiatan ini diarahkan dengan tujuan untuk meningkatkan komptensi, ketrampilan, sikap, pemahaman, dan performansi yang dibutuhkan oleh guru saat ini dan di masa mendatang. 


\section{Faktok Pendukung dan Penghambat dalam Pengembangan Profesionalitas Guru PAI di SMA PRIMAGANDA Jombang}

Faktor pendukung dan penghambaat dalam pengembangan profesionalitas tentu ada. Karena tidak mungkin setiap misi selalu berjalan dengan lancar. Begitu pula dengan pengembangan profesionalitas guru PAI di SMA PRIMAGANDA, tentu ada pula factor pendukung daan penghambatnya.

a. Faktor pendukung

Faktor pendukung dalam pengembangan profesionalitas guru PAI di SMA PRIMAGANDA Jombang ada dua, yaitu:

1) Adanya dukungan dari luar, yaitu dukungan dari Kepala sekolah dan Waka kurikulim. Selain itu, sarana dan prasarana yang memadai, kesejahteraan guru (kenaikan gaji) tunjangan sertifikasi dan penghargaan-penghargaan. Dalam setiap ruang kelas disedialan LCD proyektor untuk pembelajaran, sound system dan kipas angin. Tersedia pula masjid di area sekolah yang sewaktu-waktu bisa dijadikan tempat praktek materi PAI dan pembiasaan.

2) Dukungan dari dalam diri guru secara pribadi untuk lebih professional dalam berprofesi sebagai guru PAI. Hal ini ditandai dengan adanya bimbingan rutin, work shop, dan MGMP PAI yang tidak pernah dilewatkan oleh guru PAI di SMA PRIMAGANDA Jombang. Serta antusias guru untuk menambah pengetahuan dengan meraih pendidikan sampai jenjang S-2 (Strata 2).

b. Faktor Penghambat

Faktor penghambat dalam pengembangan profesionalitas guru PAI di SMA PRIMAGANDA Jombang yaitu: pertama, pembiayaan yang kurang, sehingga pengembangan profesionalitas tidak terealisasi sesuai dengan harapan. Yang dimaksud di sini adalah uang transport untuk mengikuti MGMP dan work shop, serta tidak adanya pembiayaan dari sekolah bagi guru untuk melanjutkan pendidikan S-2. Ke dua, durasi waktu dalam pembelajaran PAI yang kurang, sehingga kurang maksimal dalam penyampaian materi. 
Namun sebagai guru yang profesional, mereka tidak akan mempersoalkan hambatan yang ada, melainkan mereka akan selalu berupaya untuk meningkatkan profesionalitasnya dalam berbagai bidang. Semua faktorfaktor penghambat tersebut bisa diatasi jika semua pihak mau bekerja keras dan bekerja sama.

\section{Kesimpulan}

Pada dasarnya guru-guru PAI di SMA PRIMAGANDA Jombang memberikan pemikiran positif bagi pengembangan profesioanlitas mereka melalui berbagai metode yang dilakukan, baik dari dalam dirinya seperti pengembangan kualitas seperti mengikuti pelatihan dan lain-lain. Misalnya pelatihan yang telah diikuti oleh para guru PAI yaitu Musyawarah Guru Mata Pelajaran (MGMP), sarasehan antar guru SMA, mengikuti work shop atau penataran yang dilaksanakan oleh Mendikbud Jombang. Sikap demikian memberikan pandangan bahwa profesionalitas seorang guru Agama Islam bukanlah sekedar seorang guru dalam mendidik muridnya, akan tetapi umat yang wajib saling mengingatkan bahwa sebagai hamba Allah wajib melaksanakan ibadah yang telah digariskan oleh-Nya kepada kita.

Faktor pendukung dalam pengembangan profesionalitas guru PAI di SMA PRIMAGANDA Jombang yaitu: Adanya dukungan dari luar, yaitu dukungan dari Kepala sekolah dan Waka kurikulim. Selain itu, sarana dan prasarana yang memadai, kesejahteraan guru (kenaikan gaji) tunjangan sertifikasi dan penghargaan-penghargaan. Dalam setiap ruang kelas disedialan LCD proyektor untuk pembelajaran, sound system dan kipas angin. Tersedia pula masjid di area sekolah yang sewaktu-waktu bisa dijadikan tempat praktek materi PAI dan pembiasaan. Dukungan dari dalam diri guru secara pribadi untuk lebih professional dalam berprofesi sebagai guru PAI. Hal ini ditandai dengan keikut sertaan guru PAI di SMA PRIMAGANDA Jombang akan bimbingan rutin, work shop, dan MGMP PAI yang tidak pernah dilewatkan. Serta antusias guru untuk menambah pengetahuan dengan meraih pendidikan sampai jenjang S-2 (Strata 2). Faktor penghambat yaitu: Pertama, pembiayaan yang kurang, sehingga pengembangan profesionalitas tidak terealisasi sesuai dengan harapan. Ke dua, 
durasi waktu dalam pembelajaran PAI yang kurang, sehingga kurang maksimal dalam penyampaian materi. Namun, faktor-faktor penghambat tersebut bisa diatasi jika semua pihak mau bekerja keras dan bekerja sama. 


\section{Daftar Rujukan}

Sahertian, Piet, 2002. Konsep Dasar dan Teknik Pendidikan dalam Rangka Pengembangan SDM, Jakarta, Rineka Cipt

Sahertian, Piet, 1999. Profil Pendidik Profesional, Yogyakarta : Andi Offest, Samana, 1994, Profesionalisme Keguruan; Kompetensi dan Pengembangannya, Yogyakarta: Kanisius

Abdul Majid dan Jusuf Mudzakir, 2006. Ilmu Pendidikan Islam, Jakarta: Kencana Ahmad Munjin Nasih dan Lilik Nur Kholidah, Metode dan Teknik Pembelajaran Pendidikan Agama Islam, Jakarta: Refika Aditama

Atmodiworio, Soebagio, 2000. Manajemen Pendidikan Indonesia, Jakarta; Ardadizya Jaya

Bahri Djamarah, Syaiful, 1991. Prestasi Belajar dan Kompetensi Mengajar, Surabaya : Usaha Nasional

Cece Wijaya, Tabrani Rusyan, 2000. Kemampuan Dasar Guru Dalam Proses Belajar Mengajar, Bandung : Remaja Rosdakarya

Daien Indrakusuma, Amier, 1999. Pengantar Ilmu Pendidikan, Surabaya : Usaha Nasional

Gunawan, H. 1996. Kebijakan-kebijakan Pendidikan di Indonesia, Jakarta: Bina Aksara

Hamalik, Oemar, 2010. Kurikulum dan Pembelajaran,Jakarta, Bumi Aksara Hasbullah, 1999. Dasar-dasar Ilmu Pendidikan, Jakarta : Rajawali

Kosasi, Raflis, 1999. Profesi Keguruan, Jakarta; Rineka Cipta,

Kunandar, 2009. Guru Profesional Implementasi Kurikulum Tingkat Satuan Pendidikan (KTSP) dan Sukses dalam Sertifikasi Guru, Jakarta: Rajagrafindo Persada

Labib Mz., 2004. Ringkasan Ihya'ulumuddin, Upaya menghidupkan Ilmu Agama, Surabaya, Bintang Usaha Jaya

M.H. Matondang, 2010. Kepemimpinan, Budaya Organisasi dan Manajemen Stratejik, Yogyakarta: Andi Offest 
Mahyuddin, Barni, 2011. Pendidikan Dalam Perspektif Al-Qur'an, Yogyakarta: Pustaka Prisma

Majid, Abdul, 2008. Perencanaan Pembelajaran Mengembangkan Standar Kompetensi Guru, Bandung: Remaja Rosdakarya

Muhaimin, 2003. Wacana Pengembangan Pendidikan Islam, Yogyakarta: Pustaka Pelajar

Nurdin, Muhamad, 2004. Kiat Menjadi Guru Profesional, Yogyakarta : Prismasophie

Nurdin, Syafruddin, 2002. Guru Profesional dan Implementasi Kurikulum, Jakarta; Ciputat Pers

Putra Daulay, Haidar, 2006. Pendidikan Islam dalam Sistem Pendidiikan Nasional di Indonesia, Jakarta: Kencana

Santoso, Hari, 2010. Kompetensi Profesional dan Jiwa Kepemimpinan Guru, Jakarta: Rineke Cipta

Tim Instruktur, 2011. Pendidikan dan Latihan Profesi Guru (PLPG), Surabaya: LPTK Rayon 11

Trianto, 2007. Model-model Pembelajaran Inovatif Berorientasi Konstruktifistik, Jakarta, Prestasi Pustaka

Umi Machmudah dan Abdul Wahab Rosyidi, 2008. Active Learning dalam Pembelajaran Bahasa Arab, Malang: UIN-Malang Press

Uno B, Hamzah., 2010. Profesi Kependidikan, Jakarta: Bumi Aksara

Yamin, Martinis, 2008. Profesionalisasi Guru \& Implementasi KTSP, Jakarta: Gaung Persada Press 
Ali Mustofa

138 Annaba : Jurnal Pendidikan Islam 